Jurnal Pendidikan Dasar PerKhasa

Volume 4, Nomor 2, Oktober 2018

\title{
MENINGKATKAN MOTIVASI DAN HASIL BELAJAR ROLL DEPAN DENGAN ALAT BANTU BOLA LONCENG PADA SISWA KELAS V SEMESTER 2 SD NEGERI 3 PAKIS KECAMATAN KRADENAN KABUPATEN GROBOGAN TAHUN PELAJARAN 2017/2018
}

\author{
Rohanto \\ SD Negeri 3 Pakis, UPTD Pendidikan Kecamatan Kradenan Kabupaten Grobogan \\ Jl.Raya Kuwu-Sragen KM.06 Provinsi Jawa Tengah \\ email: rohanto@gmail.com
}

\begin{abstract}
The purpose of this research was to find out the efforts to improve the front roll learning with bell ball aids for the fifth grade students of SD Negeri 3 Pakis, Kradenan District. The research method used is classroom action research. The results obtained in fifth grade students of SD Negeri 3 Pakis totaling 39 students are (1) In the pre-cycle learning activities of students during the front roll floor gymnastic learning process are students complete as many as 21 students with a percentage of $53.85 \%$, and students have not completed as much 18 students with a percentage of $46.15 \%$. (2) In learning using a bell ball aid in the first cycle, students complete 29 with a percentage of $74.36 \%$, students who have not completed as much as 10 with a percentage of $25.64 \%$. (3) The results of the research on cycle 2 students complete to 35 with a percentage of $89.75 \%$ and only 4 students or $10.25 \%$ that have not been completed. From the available data, it can be concluded that the use of bell ball aids in front roll floor gymnastic learning can improve significant learning outcomes for grade V students of SD Negeri 3 Pakis. Students look interested, active, enthusiastic, paying attention and can follow the front roll learning process.
\end{abstract}

Keywords: Motivation, Learning Outcomes, Front Roll, Bell Ball Aids

Abstrak:Tujuan dalam penelitian ini adalah untuk mengetahui upaya meningkatkan pembelajaran roll depan dengan alat bantu bola lonceng pada siswa kelas $V$ SD Negeri 3 Pakis Kecamatan Kradenan. Metode penelitian yang digunakan adalah classroom action research (penelitian tindakan kelas). Hasil penelitian yang diperoleh pada siswa kelas $\mathrm{V}$ SD Negeri 3 Pakis yang berjumlah 39 siswa adalah (1) Pada pembelajaran pra siklus aktivitas siswa selama mengikuti proses pembelajaran senam lantai roll depan adalah siswa tuntas sebanyak 21 siswa dengan prosentase $53.85 \%$, dan siswa belum tuntas sebanyak 18 siswa dengan prosentase 46.15\%. (2) Pada pembelajaran dengan menggunakan alat bantu bola lonceng pada siklus I menjadi siswa tuntas sebanyak 29 dengan prosentase $74.36 \%$, siswa yang belum tuntas sebanyak 10 dengan prosentase 25.64\%. (3) Hasil penelitian pada siklus 2 siswa tuntas menjadi 35 dengan prosentase $89.75 \%$ dan hanya 4 siswa atau $10.25 \%$ yang belum tuntas. Dari data yang ada maka dapat disimpulkan bahwa penggunaan alat bantu bola lonceng dalam pembelajaran senam lantai roll depan dapat meningkatkan hasil belajar yang signifikan bagi siswa kelas V SD Negeri 3 Pakis, Siswa terlihat tertarik, aktif, antusias, memperhatikan dan dapat mengikuti proses pembelajaran roll depan.

Kata Kunci: Motivasi, Hasil Belajar, Roll Depan, Alat Bantu Bola Lonceng 


\section{Pendahuluan}

Upaya

meningkatkan

pembelajaran pada dasarnya merupakan bentuk pembelajaran guna memperbaiki kemampuan peserta didik dalam pembelajaran penjasorkes dari awal sampai akhir yang disajikan secara khas oleh guru.Salah satu masalah utama dalam Penjasorkes di Indonesia dewasa ini ialah belum efektifnya pengajaran Penjasorkes di sekolah-sekolah. Hal ini disebabkan beberapa faktor diantaranya terbatasnya sarana dan prasarana yang digunakan untuk mendukung proses pembelajaran Penjasorkes dan terbatasnya kemampuan guru Penjasorkes untuk melakukan pembelajaran Penjasorkes.Salah satu keterbatasan guru Penjasorkes dalam proses belajar mengajar adalah dalam hal menciptakan situasi lingkungan yang memungkinkan siswa untuk berinteraksi sehingga terjadi perubahan atau perkembangan pada diri siswa.

Fenomena itulah yang saat ini terjadi pada siswa kelas $\mathrm{V}$ di SD Negeri 3 Pakis dalam pembelajaran materi roll depan. Untuk mengatasi masalah tersebut, maka kami sebagai guru penjasorkes mencoba untuk melaksanakan kegiatan penelitian tindakan kelas dengan judul "Upaya
Meningkatkan Motivasi dan Hasil Belajar Roll Depan dengan Alat Bantu Bola Lonceng pada Siswa Kelas V Semester 2 SD Negeri 3 Pakis Kecamatan Kradenan Kabupaten Grobogan Tahun Pelajaran 2017/2018".

Suatu penelitian tentu mempunyai permasalahan yang perlu diteliti, dianalisis, dan diusahakan pemecahannya.Dalam penelitian ini permasalahan yang perlu dirumuskan adalah "Bagaimana Upaya Meningkatkan Pembelajaran Roll Depan dengan Alat Bantu Bola Lonceng pada Siswa Kelas V SD Negeri 3 Pakis?"

\section{Metode}

Penelitian ini dilaksanakan dengan metode perlakuan proses pembelajaran senamketangkasan roll depan dalam penjasorkes dengan alat bantu bola lonceng melalui pendekatan Penelitian Tindakan Kelas (PTK).

Penelitian ini dilaksanakan di SD Negeri 3 Pakis. Sebagai subjek dalam penelitian ini adalah siswa kelas $\mathrm{V} S \mathrm{SD}$ Negeri 3 Pakis, dengan jumlah siswa sebanyak 39 anak yang terdiri dari 26 laki-laki dan 13 perempuan. Sebagai obyek dalam penelitian senam ketangkasan roll depan pada siswa kelas V SD Negeri 3 Pakis. Penelitian 
Meningkatkan Motivasi dan Hasil Belajar...

dilaksanakan pada bulan Januari-Juni tahun 2018 semester genap tahun pelajaran 2017/2018.

Sesuai dengan jenis penelitian yang dipilih, yaitu penelitian tindakan, maka penelitian ini menggunakan model penelitian tindakan dari Kemmis dan Taggart (dalam Arikunto, 2002:83), yaitu berbentuk spiral dari siklus yang satu ke siklus yang berikutnya.Setiap siklus meliputi planning (rencana), action (tindakan), observation (pengamatan), dan reflection (refleksi).Langkah pada siklus berikutnya adalah perencanaan yang sudah direvisi, tindakan, pengamatan, dan refleksi.Sebelum masuk pada siklus 1 dilakukan tindakan pendahuluan yang berupa identifikasi permasalahan.

Pelaksanaan penelitian senam ketangkasan roll depan, dilaksanakan di halaman SD Negeri 3 Pakis. Di dalam penelitian ini, pengambilan data dilaksanakan sebanyak dua kali yaitu siklus I dan sklus II.

Adapun data tentang proses belajar mengajar pada saat dilaksanakan tindakan kelas dengan lembar observasi. Teknik pengumpulan data yang digunakan untuk memperoleh data dalam penelitian ini adalah tes dan obsevasi.Kegiatan ini digunakan untuk mengumpulkan data sebagai bahan refleksi dan analisis.Observasi dilakukan sendiri oleh guru dan peneliti untuk mendapatkan data yang rinci dan akurat. Instrumen pengumpulan data dengan metode tes, dokumentasi, kuesioner.Analisis data yang digunakan dalam penelitian meliputi aspek kognitif, afektif dan psikomotor.Prosedur penelitian yang dilakukan yaknipenelitian tindakan kelas terdiri atas dua siklus. Penelitian tindakan kelas ditujukan untuk meningkatkan hasil belajar siswa materi pokok roll depan. Setiap siklus mencakup empat tahapan yaitu perencanaan, tindakan, pengamatan dan refleksi.

Pada penelitian ini menggunakan teknik analisis deskriptif kualitatif, yaitu suatu metode penelitian yang bersifat menggambarkan kenyataan atau fakta sesuai dengan data yang diperoleh dengan tujuan untuk mengetahui prestasi belajar yang dicapai siswa juga untuk memperoleh respon siswa terhadap kegiatan pembelajaran serta aktivitas siswa selama proses pembelajaran.

Untuk menilai ulangan atau tes formatif, Peneliti melakukan penjumlahan nilai yang diperoleh siswa, yang selanjutnya dibagi dengan jumlah siswa yang ada di kelas tersebut sehingga diperoleh rata-rata tes formatif. 
Untuk ketuntasan belajar, ada dua kategori ketuntasan belajar yaitu secara perorangan dan secara klasikal. Berdasarkan petunjuk pelaksanaan belajar yaitu seorang siswa telah tuntas belajar bila telah mencapai skor diatas 70. Menurut Depdiknas (2006: 62), secara klasikal proses belajar mengajar dikatakan tuntas apabila di kelas memperoleh nilai $\geq 70$ sebanyak $85 \%$.

\section{Hasil dan Pembahasan}

Proses penelitian dilaksanakan dalam 2 siklus yang masing-masing siklus terdiri dari 4 tahapan, yakni: (1) perencanaan, (2) pelaksanaan tindakan, (3) observasi dan interpretasi, dan (4) analisis dan refleksi. Data yang diperoleh dari hasil penelitian berupa data numerik (angka) yang kemudian dianalisis untuk membuktikan hipotesis yang diajukan.

Pada pembelajaran pra siklus aktivitas siswa selama mengikuti proses pembelajaran senam lantai roll depan adalah siswa tuntas sebanyak 21 siswa dengan prosentase $53.85 \%$ dan siswa belum tuntas sebanyak 18 siswa dengan prosentase 46.15\%. Pada pembelajaran dengan menggunakan alat bantu bola lonceng pada siklus I hasil belajar siswa mengalami peningkatan yaitu siswa tuntas sebanyak 29 dengan prosentase
74.36\%, siswa yang belum tuntas sebanyak 10 dengan prosentase $25.64 \%$.

Dapat diketahui bahwa dengan pembelajaran dengan menggunakan alat bantu bola lonceng yang awalnya pada siklus I siswa yang tuntas 29 dan siswa yang belum tuntas ada 10. Pada siklus II mengalami peningkatan yaitu siswa yang tuntas sebanyak 35 dengan prosentase $89,75 \%$, dan siswa yang belum tuntas hanya 4 siswa saja.

Sebagai pembahasan, pada siklus 1 dari hasil pengamatan dan hasil angket respon siswa terhadap proses pembelajaran yang telah berlangsung, diperoleh hasil penilaian yang meliputi aspek psikomotorik, kognitif dan afektif mengalami peningkatan dari sebelum diadakan penelitian tindakan kelas (pra siklus), yaitu semula 21 siswa atau sebesar 53.85\% yang sudah dinyatakan tuntas menjadi 29 siswa atau 74.36\% sudah dinyatakan tuntas belajar.

Berdasarkan hasil penelitian diapatkan bahwa masih ada kekurangan yang diperoleh pada siklus 1, maka peneliti sebagai sumber belajar melakukan perbaikan pada siklus 2 . Perbaikan-perbaikan tersebut antara lain : (1) Siswa diharapkan menikmati proses pembelajaran roll depan dengan alat bantu bola lonceng (2) Penambahan 
Meningkatkan Motivasi dan Hasil Belajar...

media matras kecil diletakkan dibawah matras besar dibagian depan guna lebih memudahkan untuk mengguling.

Diharapkan pembelajaran pembelajaran roll depan dengan alat bantu bola lonceng merupakan pembelajaran yang menarik dan menyenangkan bagi siswa.

(4) Memberi reward atau penguatan kepada siswa agar tertarik dan menyukai pelajaran.

Pada siklus II pengamatan dan hasil angket respon siswa terhadap proses pembelajaran yang telah berlangsung, diperoleh hasil penilaian yang meliputi aspek psikomotorik, kognitif dan afektif mengalami peningkatan dari siklus 1 , yaitu semula 29 siswa atau sebesar $74.36 \%$ yang sudah dinyatakan tuntas menjadi 35 siswa atau $89.75 \%$ sudah dinyatakan tuntas belajar. Selama proses pembelajaran pada siklus 2 , siswa terlihat serius mengikuti petunjuk dan arahan dari guru, siswa terlihat disipilin, bersemangat, percaya diri dan berani selama proses pembelajaran berlangsung. Sehingga hasil pembelajaran pada siklus 2 sudah maksimal sesuai dengan tujuan pembelajaran yang diharapkan. Keberhasilan peningkatan hasil belajar senam ketangkasan roll depan pada siswa kelas V SD Negeri 3 Pakis menggunakan alat bantu bola lonceng sebagai berikut : (1) Media pembelajaran yang dilakukan merupakan suatu media pembelajaran yang tergolong baru bagi siswa dan belum pernah didapat sebelumnya sehingga memberi pengalaman baru bagi siswa. (2) Pendekatan pembelajaran dengan media alat bantu merupakan model pembelajaran yang menarik bagi siswa. (3) Minat siswa untuk belajar roll depan bertambah karena siswa menganggap belajar roll depan dengan menggunakan alat bantu bola lonceng Imerupakan pembelajaran yang menarik dan menambah wawasan serta pengalaman.

\section{Simpulan dan Saran}

Upaya yang dilakukan dalam penelitian ini yaitu dengan menggunakan aplikasi model pembelajaran menggunakan media alat bantu bola lonceng untuk meningkatkan motivasi pembelajaran roll depan pada siswa kelas V SD Negeri 3 Pakis. Berdasarkan pada hasil penelitian yang sudah dilakukan, maka dapat disimpulkan sebagai berikut: Siswa terlihat tertarik, aktif dan antusias dalam mengikuti proses pembelajaran roll depan. Siswa terlihat memperhatikan pelajaran dengan serius dan terlihat aktif dalam kegiatan 
belajar mengajar. Hal ini ditunjukkan pada prosentase peningkatan ketuntasan belajar siswa yang awalnya pada pra siklus hanya $53.85 \%$ siswa yang tuntas, kemudian meningkat 74.36 pada siklus I dan pada siklus II meningkat lagi menjadi 89.75\%.

Dari hasil penelitian yang diperoleh dari uraian sebelumnya agar proses belajar menggunakan aplikasi model pembelajaran menggunakan media alat bantu bola lonceng lebih memberikan hasil yang optimal bagi siswa, maka disampaikan saran sebagai berikut: (1) Untuk melaksanakan pembelajaran terstruktur dengan pemberian tugas memerlukan persiapan yang cukup matang. (2) Dalam rangka meningkatkan pembejaran roll depan, guru hendaknya lebih sering melatih siswa dengan berbagai metode, walau dalam taraf yang sederhana, dimana siswa nantinya dapat menemukan pengetahuan baru, memperoleh konsep dan keterampilan, sehingga siswa berhasil atau mampu mengatasi kekurangannya.(3) Perlu adanya penelitian yang lebih lanjut, karena hasil penelitian ini hanya dilakukan di SD Negeri 3 Pakis. (4) Untuk penelitian yang serupa hendaknya dilakukan perbaikan-perbaikan agar diperoleh hasil yang lebih baik.

\section{Daftar Pustaka}

Agusta, Hendra. 2009. Pola Gerak Dalam Senam 1. Jakarta: CV Ipa Abong.

Ahmad, Satrio Y. 2007. Senam. Jakarta: PT. Indah Jaya.

Arikunto, S. 2002. Prosedur Penelitian, Suatu Pendekatan Praktek. Jakarta: PT Rineka Cipta.

Arsyad, Azhar. 2007. Media Pembelajaran. Jakarta: PT. Raja Grafindo Persada.

Dadan Heryana. 2010. Pendidikan Jasmani Olahraga dan Kesehatan. Jakarta:Pusat Pembukuan, Kementrian Pendidikan Nasional.

Deni Kurniadi, Suro Prapanca. 2010. Penjas Orkes untuk Sekolah Dasar Kelas VI.Jakarta : PT. Adhi Aksara Abadi Indonesia.

Farida Mulyaningsih. dkk. 2010. Pendidikan Jasmani, Olahraga dan Kesehatan untuk Kelas IV SD/MI. Jakarta: Pusat Perbukuan Kementerian Pendidikan Nasional.

Hamalik, Oemar. 2004. Proses Belajar Mengajar. Jakarta: Bumi Aksara

Mahendra,Agus. 2003. Pembelajaran Senam di Sekolah Dasar. Sebuah Pendekatan Pembinaan Pola Gerak Dominan. Jakarta : Direktorat Jenderal Olahraga, Depdikdas.

Muhajir, Adipratama. 2004.Pendidikan Jasmani Teori dan Praktik 1. Jakarta:Erlangga 